\title{
A Survey of Agglomeration Determinants in Indonesia
}

\author{
Imamudin Yuliadi \\ Business and Economics Faculty, \\ Universitas Muhammadiyah Yogyakarta, \\ Jl. Brawijaya, Geblagan, Tamantirto, Kec. Kasihan, \\ Yogyakarta, Daerah Istimewa Yogyakarta 55183, Indonesia
}

DOI: https://doi.org/10.36941/ajis-2021-0026

\begin{abstract}
This study aims to analyze the determinants of agglomeration in Indonesia by including research variables, namely the Exchange Rate (ER), Agglomeration, Williamson index (IW), Regional Income (RI), Domestic Investment (DI), Length of Road (LR), and Regional Expenditures (RB). The analysis method in this research was to estimate panel data and econometric tests, including heteroscedasticity test, multicollinearity test, Chow test, Hausman test, and t-statistic test. The data were obtained from Bank Indonesia (BI), and the Central Statistics Agency (BPS) from 2010 to 2017. The results of the study showed that agglomeration in Indonesia was affected by changes in the Exchange Rate (ER), Regional Expenditure (RB), Regional Income (RI), Domestic Investment (DI), Length of Road (LR), and Williamson index (IW). An integrated policy needs to be formulated to improve economic efficiency through the development of production chains and the utilization of regional economies to encourage national economic growth.
\end{abstract}

Keywords: Agglomeration, Multiplier effect, Economic efficiency, Industrialization

\section{Introduction}

Research on this agglomeration is relatively rare and interesting to study because it covers a large area with 34 provinces in Indonesia, with a total population of around 271 million people. An essential contribution of this study compared to previous research is the combination of macroeconomic variables, regional finance, infrastructure, and the economic disparity that affects the agglomeration in Indonesia.

Economic agglomeration is the implication of economic development through an industrialization strategy that causes the integration and convergence of economic development components, concerning location, the supply of raw materials, labor, capital, and marketing strategies (Menon, 2008; Silverman and Brians, S, 1999). The agglomeration phenomenon is influenced by local economic factors, namely the quality of human resources, road infrastructure networks, electricity networks, PDAMs, bridges, ports, airports, and others. (Thomson, et al. 2005; Kuncoro, 2000). Economic agglomeration is also influenced by the economic policies implemented by local governments and the response of economic actors to the policies implemented (Rotenberg et al., 200o; Laura Alfaro and Maggie Chen, 2014). Theoretically, agglomeration is an effort of business actors to improve business efficiency and productivity so that economic activity can run optimally (Paula Guimaraes, et al. 2000; Zhang, 2016.) The following figure describes investment development, which is a significant factor in agglomeration in Indonesia: 


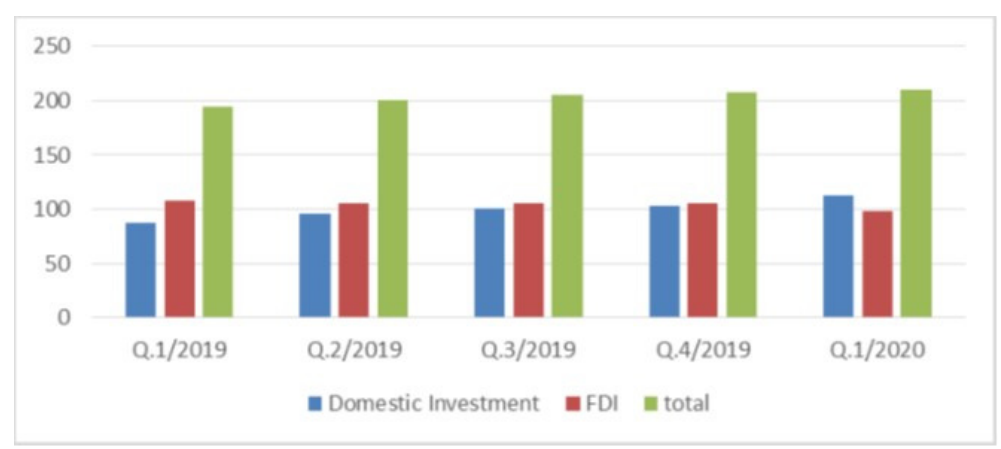

Figure 1. Investment in Indonesia (billion rupiahs)

Source: Statistics of Indonesia, 2020

The implementation of agglomeration in Indonesia is manifested in the form of a special economic zone (SEZs) development policy as an effort to encourage regional economic growth in particular and nationally in general. (Kuncoro, 2002; Holmes, Thomas. J, 1998). The development of special economic zones (SEZs) is determined based on the selection of regions that have geo-economic and geostrategic advantages to encourage economic growth in the region as a growth center (Diamond, Charles A, and Curtis J. Simon, 1990).

\section{Theoretical Framework}

Agglomeration is a development process that involves several stakeholders and has implications for the use of resources based on aspects of uniqueness and territoriality (Greenstone, Michael, et al., 2008; Vernon, 2003). The aggregate growth model is a growth model based on contributions from economic sectors in an economy. The aggregate growth model is expected to obtain information about the contribution of economic sectors to the aggregate economy (David, et al., 2007; Arzaghi, Mohammad, 2008; Hidayati, Amini, and Mudrajad Kuncoro, 2004). The process of agglomeration and economic growth requires investment through an increase in public savings, which is characterized by a shift upward the $\mathrm{f}\left(\mathrm{k}^{*}\right)$ curve that will move the economy towards a steady-state with lower consumption, as illustrated in the following curve (Mankiw, 2006):

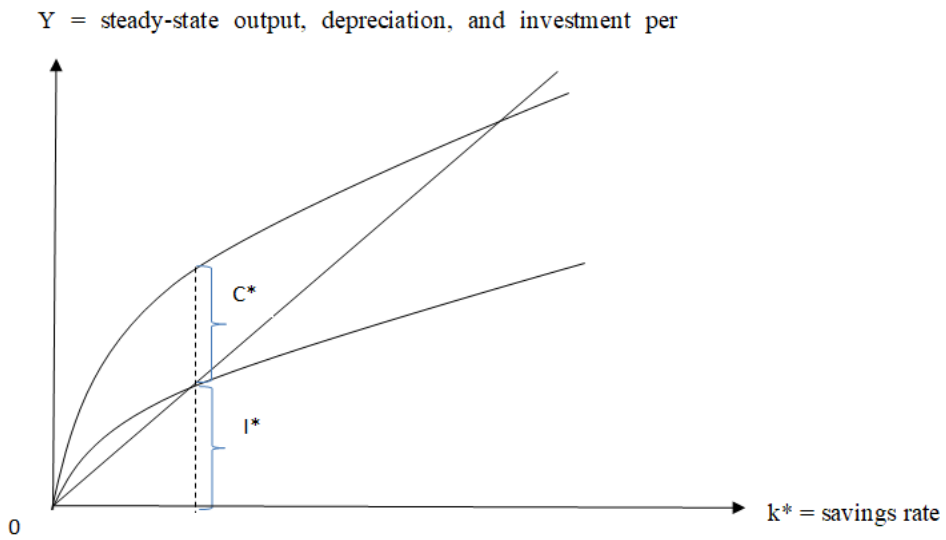

Figure 2. The Rule of Golden at Steady State

Source: Mankiw, N.G, Macroeconomics, 2006, p. 197 
The phenomenon of agglomeration is part of the industrialization process to improve efficiency in developing countries to increase productivity and overcome the problem of economic dependence on developed countries (Diamond, Charles and Curtis J. Simon, 1990; Dumais, Guy, 2002). To overcome the problem of dependency, a significant amount of capital support is needed, as stated in the "Big Push Theory of Development", which states that developing countries need massive financial assistance (Misra and Puri, 2010; Glaeser, Edward, and Matthew E. Kahn, 2001). The theory of development regarding agglomeration can also be seen in the context of dependency theory in development, as proposed by Lester R Brown who looks at the phenomenon of developing countries' dependence on developed countries (Brown, Lester, 2015; Pimentel, Harper, \& Martin, 2016). The dependence is related to the dependence of capital, technology, experts, input, and markets, causing a permanent economic gap between developing and developed countries (Ellison, Glenn, 2010; Holmes, Thomas. J, 1998). Agglomeration, which is connoted by increasing productivity through integration of several companies in a region, can be shown by the existence of an economic growth curve through increased investment (Glaeser, Edward L, and Janet K. Kohlhase, 2004; Hoover, Edgar Malone, 1948). This condition indicates the process of economic growth caused by an increase in the number of factors producing labor, land, and capital (Kerr, William R, 2008; Jaffe, Adam B, et al., 2000). The agglomeration process as part of the development process shows the greater ability of the economy to produce goods and services to meet its people's economic needs (Kim, Sukkoo, 1999; Puga, Diego, 2010)

\section{Research Methodology}

Research on the Determinant of Agglomeration in Indonesia's 34 provinces was to investigate the factors that influenced the magnitude of agglomeration in Indonesia from 2010-2017. In this study, the independent variable was the Total Population (thousand people), Regional Expenditure (million rupiahs), Regional Income (million rupiahs), and Human Development Index (HDI). Meanwhile, the dependent variable was agglomeration (million rupiahs).

\subsection{Data and Model Analysis}

The estimation model of the Agglomeration Determinant research in Indonesia is formulated as follows:

$$
\begin{aligned}
& \mathrm{Y}=\alpha_{0}+\alpha_{1} \mathrm{X}_{\text {iit }}+\alpha_{2} \mathrm{X}_{2 \mathrm{it}}+\alpha_{3} \mathrm{X}_{3 \mathrm{it}}+\alpha_{4} \mathrm{X}_{4 \mathrm{it}}+\alpha_{5} \mathrm{X}_{5 \mathrm{it}}+\alpha_{6} \mathrm{X}_{6 \mathrm{it}} \\
& \text { Where: } \\
& \mathrm{Y}=\text { Agglomeration } \\
& \mathrm{X}_{\text {iit }}=\text { Exchange rate (ER) in the i-region in t-year } \\
& \mathrm{X}_{2 \mathrm{it}}=\text { The length of the road (LR) in the i-area in the t-year } \\
& \mathrm{X}_{3 \mathrm{it}}=\text { Regional Expenditures (RB) in the i-area in the t-year } \\
& \mathrm{X}_{4 \text { it }}=\text { Regional Income (RI) in the i-region in t-year } \\
& \mathrm{X}_{5 \text { it }}=\text { Domestic investment (DI) in the i-region in the t-year } \\
& \mathrm{X}_{6 \mathrm{it}}=\text { Williamson Index (IW) in the i-region in the t-year }
\end{aligned}
$$

The exchange rate (ER) is an important factor in influencing the price of imported capital goods to meet industrial raw materials' needs. Exchange rate fluctuations will affect production costs and the allocation of raw materials in producing goods that will be partially exported. Road infrastructure is the main access in smoothing the flow of goods and capital in sustaining industrialization activities in an area that has a long road and good road quality, which will provide a more promising business climate so that industrialization develops better (Glaeser, Edward L, and Janet K. Kohlhase, 2004). The contribution of regional finances through regional expenditure and regional own-source revenue greatly influences the readiness of a region in encouraging industrialization in the region (Epaphra, M., 2017). The allocation of regional expenditure is used to improve the quality of public services and economic facilities so that the investment climate is more vibrant (Blanchard, Oliver, and Roberto Perotti, 2002). Socio-economic conditions through the Williamson index indicator will explain how the 
socio-economic aspects influence on industrialization and agglomeration in Indonesia (Dumais, Guy, Glenn Ellison, and Edward L. Glaeser, 2002)

The panel data research model's estimation was done through several approaches, namely Common Effect Model, which is the simplest panel data estimation model because it is enough to combine time series data with cross-section. The panel data research model's estimation with a common effect model approach can be done through OLS (ordinary least square) method (Gujarati, 2004).

$Y_{i t}=\alpha+X_{i t} \beta_{i t}$

The fixed effect model is a panel data estimation model, assuming that differences between individual data are accommodated through intercept differences. The estimation model was performed using the least square dummy variable (LSDV) method (Gujarati, 2004).

$$
\begin{aligned}
& Y_{\text {it }}=\alpha+\text { i. } \alpha_{\text {it }}+X_{\text {it } \beta}^{\prime}+\varepsilon_{\text {it }} \\
& {\left[\begin{array}{l}
Y_{1} \\
Y_{2} \\
Y_{3}
\end{array}\right]=\left[\begin{array}{l}
a \\
a \\
a
\end{array}\right]+\left[\begin{array}{lll}
1 & 0 & 0 \\
0 & 1 & 0 \\
0 & 0 & 1
\end{array}\right]+\left[\begin{array}{l}
a_{1} \\
a_{2} \\
a_{3}
\end{array}\right]+\left[\begin{array}{lll}
X_{1.1} & X_{2.1} & X_{1.1} \\
X_{1.2} & X_{2.2} & X_{1.1} \\
X_{1.3} & X_{2.3} & X_{1.1}
\end{array}\right]+\left[\begin{array}{l}
\beta_{1} \\
\beta_{1} \\
\beta_{1}
\end{array}\right]+\left[\begin{array}{l}
\beta_{1} \\
\beta_{1} \\
\beta_{1}
\end{array}\right]}
\end{aligned}
$$

The random effect model is a panel data estimation model where error terms for each individual are accommodated based on differences in time and place. The estimation model of the panel data estimation approach to the random effect model also eliminates the problem of heteroscedasticity. The estimation model is the Generalized Least Square (GLS) or error component model (ECM) technique (Gujarati, 2004).

$$
\begin{aligned}
& Y_{\text {it }}=\alpha+X_{i i t}+\omega_{\text {it }} \\
& \text { Where: } \\
& \omega_{\text {it }}=\varepsilon_{\text {it }}+\mathrm{u} ; \theta=0 ;\left(\omega_{\text {it }}\right)+\alpha_{2}+\alpha_{\mathrm{u} 2} \\
& \omega_{\text {itt }}^{\prime} \omega_{\text {it }}-1=0 ; \mathrm{I} \neq \mathrm{j} ; \mathrm{E}\left(\mathrm{u}_{\mathrm{i}}^{\prime} \varepsilon_{\mathrm{it}}\right)=\mathrm{o} \\
& \left(\varepsilon_{\mathrm{i}}^{\prime} \varepsilon_{\mathrm{ts}}\right)=\left(\varepsilon_{\mathrm{it}}^{\prime} \varepsilon_{\mathrm{js}}\right)=\mathrm{E}\left(\varepsilon_{\mathrm{i}}^{\prime} \varepsilon_{\mathrm{ts}}\right)=\mathrm{o}
\end{aligned}
$$

\subsection{Selection of Estimated Models}

The selection of the research model is a stage in the panel data analysis to determine which estimation approach model would be used, whether using a common effect model, fixed effect model, or randomeffect model. The steps taken were to conduct a Chow test to determine whether the right approach model was the fixed effect model or the common effect model. The Chow test hypothesis formulation is: (Gujarati, 2004)

Ho $=$ Common effect model

$\mathrm{Ha}=$ Fixed effect model

Information from the Chow test results above showed the probability value of o,00o $<0.05$ (error rate $\alpha=5 \%$ ). It means that Ho was rejected, indicating that the right model based on the Chow test was a fixed-effect model. The next stage of selecting the research model was to carry out the Hausman test, which was to determine whether to use the fixed-effect model or random effect model approach. The formulation of the research hypothesis is as follows: (Gujarati, 2004)

Ho $=$ Random effect model

$\mathrm{Ha}=$ Fixed effect model

Hausman test results showed that the probability value was $0.0000<<0.05$ (error rate $\alpha=5 \%$ ). It means that Ho was rejected, indicating that the right model based on the Hausman test was using a fixed-effect model approach (Gujarati, 2004).

\section{Results and Discussion}

The complete results of the estimation of the agglomeration model in Indonesia using the three analysis models obtained the following results: 
Table 1. Estimation of the Agglomeration Model in Indonesia

\begin{tabular}{lccc}
\hline \multirow{2}{*}{ Dependent Variable: Agglomeration } & & Model & \\
\cline { 2 - 4 } Constant & Common Effect & Fixed Effect & Random Effect \\
Standard Error & $-1,586930$ & 0,701007 & 0,591372 \\
Probability & 0,870151 & 0,065540 & 0,264308 \\
Log (RI) & 0.000000 & 0,000000 & 0,026300 \\
Standard Error & 0,503967 & 0,013717 & 0,053294 \\
Probability & 0.022374 & 0,003405 & 0,009554 \\
LOG (RB) & 0.000000 & 0,000100 & 0,000000 \\
Standard Error & 0,425457 & 0,001561 & 0,049254 \\
Probability & 0.027343 & 0,003645 & 0,013426 \\
LOG(LR) & 0.000000 & 0,669000 & 0,000300 \\
Standard Error & 0,197232 & $-0,028010$ & 0,024296 \\
Probability & 0.031599 & 0,008606 & 0,024910 \\
LOG(DI) & 0.000000 & 0,001300 & 0,330500 \\
Standard Error & 0,048265 & $-0,000756$ & $-0,000300$ \\
Probability & 0,009177 & 0,000199 & 0,002000 \\
WI & 0,000000 & 0,000200 & 0,880800 \\
Standard Error & 0,000252 & 0,004285 & 0,006373 \\
Probability & 0,002928 & 0,000669 & 0,001227 \\
LOG(XR) & 0,931600 & 0,000000 & 0,000000 \\
Standard Error & $-1,586930$ & $-0,015055$ & $-0,136175$ \\
Probability & 0,089625 & 0,004473 & 0,025916 \\
R 2 & 0,000000 & 0,000900 & 0,000000 \\
F-statistic & 0,964251 & 0.999953 & 0,144078 \\
Probability & 1007,986 & 125386,7 & 7,284346 \\
Durbin-Watson Stat & 0.000000 & 0.000000 & 0,000000 \\
\hline
\end{tabular}

Source: BPS data (processed)

The estimation results on the fixed-effect model above showed that all independent variables exhibited a statistically significant coefficient at an error rate of $\alpha$ of $5 \%$, except for the regional expenditure variable $(\mathrm{RB})$, which demonstrated a probability value of 0.669000 . It indicated that regional spending did not have much influence on the phenomenon of agglomeration in Indonesia. The allocation of regional expenditure is still widely used for routine expenditure compared to development expenditure for infrastructures' provisions, such as roads, bridges, electricity networks, telecommunications networks, and others. The lack of influence of regional spending in driving industrialization is related to bureaucratic characteristics that sometimes hamper the region's investment climate. It is a challenge for the Indonesian economy, which implements a regional autonomy policy. A country where more regional expenditure is allocated for infrastructure development will have a positive effect on agglomeration in the country (Glaeser, Edward L, and Matthew E. Kahn, 2001).

The coefficient of determination ( $\mathrm{R}_{2}$ ) of 0.999953 indicated that the fixed effect model was quite good in explaining the agglomeration phenomenon in Indonesia. The estimation results showed that $99.9 \%$ of the change in the agglomeration variable could be explained through changes in the independent variable in the model, including the regional income variable (RI), the length of the road (LR), regional expenditure (RB), domestic investment (DI), Williamson index (WI), and rupiah exchange rate (ER) (Adams, John, 1999, Epaphra, M., 2017)

The regression coefficient value of the Road Length variable (LR) was - 0.570450 . It means that an increase in the length of the road by $1 \%$ would reduce the value of agglomeration by $0.570450 \%$. This condition implies that the addition of road sections has not been able to move the distribution channels and transport goods and capital to the fullest (Sodik, Jamzani, and Iskandar, Dedi, 2007). It 
is due to an imbalance between the acceleration of the increase in the length of the road with the number of vehicles, causing a buildup of vehicles and congestion. This phenomenon occurs on several roads in the agglomeration industry locations, such as Bekasi, Tangerang, Jakarta, Bogor, Semarang, Malang, Surabaya, and Sidoarjo. Congestion that occurs will have an impact on increasing transportation costs and company operations. Many complaints were conveyed by road users about the number of damaged roads causing accidents. Besides that, there are still illegal levies and logging found in some vulnerable areas. Efforts made by the government through the addition of roads must be followed by driving behavior from the community, including obeying the vehicle's maximum load provisions so that road conditions can remain good and function optimally (Arzaghi, Mohammad and Vernon, 2008)

The regression coefficient of the Domestic Investment (DI) variable of - o,000756 indicated that an increase in domestic investment (DI) of $1 \%$ would reduce the value of agglomeration by $0,000756 \%$. The effect of changes was relatively small, but this empirical finding becomes interesting because it shows a negative sign, meaning that an increase in the value of the investment actually reduces the amount of agglomeration in a country (Epaphra, M. 2017.) It confirms that there are inconsistencies in managing domestic investment funds with industrialization policies in Indonesia. This empirical finding also implies that agglomeration through the policy of developing special economic zones (SEZs) relies more on government budget funding through the APBN (National Budget, Revenue, and Expenditures) or APBD (Regional Revenue and Expenditures Budget) rather than from the private sector. There is a tendency for industrialization through domestic investment to be more diffuse rather than concentrated in a particular region in accordance with the nature of the industry, which is more likely to approach the market (market-based industry). The company's strategy is to improve efficiency by building factories close to consumers to reduce transportation and operational costs, such as the food industry, garment, handicraft, household appliances, and others (Laura Alfaro, Maggie Chen, 2014; Yuliadi, 2020).

The Williamson index (WI) variable regression coefficient was 0.004285 . It means that a one-digit increase in the Williamson index would increase agglomeration by $0.004285 \%$. It shows that higher income inequality drives the increase in agglomeration in Indonesia. The phenomenon of economic inequality is one of the crucial issues in Indonesia. Theoretically and empirically, it indicates that industrialization and agglomeration affect the income inequality of society and vice versa, income inequality also affects the agglomeration process in Indonesia. Inequality of income in Indonesia, both between regions and between groups, is a result of the development that is concentrated in Java, especially in the areas of Jakarta, Bogor, Depok, Tangerang, and Bekasi (Greater Jakarta). Industrial or agglomeration concentrations also occur in several regions in Indonesia, and most of them are in Java, such as in Surabaya, Semarang, Bandung, and Malang (Redding, Stephen, 2011; Blanchard, Oliver, and Roberto Perotti, 2002)

The regression coefficient of the rupiah exchange rate variable (ER) of -0.015055 indicated that a decrease in the rupiah exchange rate (depreciation) of $1 \%$ would increase agglomeration by $0.015055 \%$. This condition shows that the weakening of the rupiah exchange rate encourages an increase in exports of industrial products, thereby increasing agglomeration. in Indonesia. This phenomenon occurs in the type of export-oriented industries and the content of raw materials from within the country (Aghevli, 1977; Thomas A. Lubik, 2018)). This fact also affirms that Indonesia's agglomeration is primarily supported by components of capital goods from abroad, such as raw materials, production machinery, and others, so that it is very sensitive to fluctuations in the rupiah exchange rate.

\section{Conclusions and Recommendations}

The conclusions from the results of research on the determinants of agglomeration in Indonesia revealed that the variables of regional income (RI) and the Williamson index (WI) had a positive and significant effect on Indonesia's agglomeration. Meanwhile, the variables of the length of the road (LR), domestic investment (DI), and the rupiah exchange rate (ER) had a negative and significant effect on 
agglomeration in Indonesia. This fact explains that the regional expenditure variable (RB) did not affect agglomeration in Indonesia.

Recommendations based on empirical findings of agglomeration in Indonesia is that optimizing the use of regional spending in improving the quality of economic infrastructure is vital to encourage agglomeration in Indonesia. Local revenue variable is a crucial component to improve the quality of public services and bureaucracy to improve an increasingly conducive investment climate. It is related to regional autonomy policy and improving the bureaucracy's quality in creating an investment climate in the region. Strategies to correct income inequality are essential in creating a better economic climate for industrialization's development in Indonesia. Improving the quality of human resources and the involvement of the potential workforce in the area of agglomeration are priorities in the development of industrialization in Indonesia. Road development as economic access must be balanced with good transportation policies and management to reduce the potential for traffic congestion that can hamper the distribution of goods and services between regions in Indonesia. Increasing the use of local components in encouraging industrialization is a strategic step in strengthening the structure of industrialization in Indonesia. Increased cooperation between the central and regional governments in creating business certainty through regulations that support investment development and production by utilizing the local economy's potential. Cooperation of policymakers with businesses in improving economic efficiency and competitiveness of industrial products in the export market. The government needs to oversee the use of development funds from the risk of corrupt practices for the construction of road infrastructure, airport bridges, ports, electricity networks, and others, which is an essential part in improving the economic efficiency of Indonesia's industry (Zhang, 2016, Yeaple, Stephen, 2003).

\section{References}

Adams, John, 1999, The Contemporary International Economy Reader, second edition, St. Martin Press, New York. Adams, John, 1985, "An Econometric Model of Monetary Sector for Indonesia”, Journal of Development Studies, 21(3). Aghevli, BB, 1976, "A Model of The Monetary Sector for Indonesia 1968-1973", Bulletin of Indonesian Economic Studies, 12/3, 50-60.

Aghevli, BB, 1977, Money, Prices, and Balance of Payments Indonesia 1968-1973, Journal of Development Studies, $13(2)$.

Arzaghi, Mohammad and J. Vernon, Henderson, 2008, Networking off Madison Avenue, Review of Economic Studies, 75(4), 1011-1038.

Autor, David H, William R. Kerr and Adriana D. Kugler, 2007, Does Employment Protection Reduce Productivity? Evidence from United States, Economic Journal, 117(521), 189-217.

Blanchard, Oliver and Roberto Perotti, 2002, An Empirical Characterization of The Dynamic Effects of Changes in Governments Tax on Outpu, MIT Press, The Quarterly Journal of Economics, 117(4), 1329-1368.

Brown, Lester, 2015, The Great Transition Shifting from Fosil Fuels to Solar and Wind Energy, Earth Policy Institute.

Diamond, Charles A and Curtis J. Simon, 1990, Industrial Specialization and The Returns of Labor, Journal of Labor Economics, 8(2), 175-201.

Dumais, Guy, Glenn Ellison and Edward L. Glaeser, 2002, Geographic Concentration as A Dynamic Process, Review of Economics and Statistics, 84(2), 193-204.

Duranton, Gilles and Henry G. Overman, 2005, Testing for Localization using Microgeographic Data, Review of Economics Studies, 72(4), 1077-1106.

Duranton, Gilles and Henry G. Overman, 2008, Exploring The Detailed Location Patterns of UK Manufacturing Industries Using Microgeographic Data, Journal of Regional Science, 48(1) 213-243.

Ellison, Glenn and Edward L. Glaeser, 1997, Geographic Concentration in United States Manufacturing Industries A Dartboard Approach, Journal of Political Economy, 105(5), 889-927.

Ellison, Glenn and Edward L. Glaeser, 1999, The Geographic Concentration of Industry Does Natural Advantage Explain Agglomeration ?, American Economic Review, 89(2), 311-316.

Ellison, Glenn, Edward L. Glaeser and William R. Kerr, 2010, What Causes Industry Agglomeration? Evidence from Coagglomeration Patterns, American Economic Review, 10o(6), 1195-1213.

Epaphra, M. (2017.). Analysis of Budget Deficit and Macroeconomics Fundamental A VAR-VECM Approach, Journal of Economics and Management, 30(4), 1-38. 
Fujita, Masahisa, Paul Krugman and Anthony J. Venables, 1999, The Spatial Economy Cities, Regions and International Trade, Cambridge MA, MIT Press.

Glaeser, Edward L, and Janet K. Kohlhase, 2004, Cities, Regions and The Decline of The Transport Costs, Papers in Regional Science, 83(1), 197-228.

Glaeser, Edward L and Matthew E. Kahn, 2001, Decentralized Employment and The Transformation of The American City, National Bereau of Economic Research Working Paper, 8117.

Greenstone, Michael, Richard Hornbeck and Enrico Moretti, 2008, Identifying Agglomeration Spillovers Evidence from Millions Dollars Plants, National Bereau of Economics Research Working Paper, 13833.

Gujarati, Damodar N, 2004, Basic Econometrics, fifth edition, McGraw-Hill, London.

Helsley, Robert W and William C Strange, 199o, Matching Agglomeration Economies in A System of Cities, Regional Science and Urban Economics, 20(2), 189-212.

Henderson, J. Vernon, 2003, Marshall's Scale Economies, Journal of Urban Economics, 53(1), 1-28.

Hidayati, Amini dan Mudrajad Kuncoro, 2004, Konsentrasi Geografis Industri Manufaktur di Greater Jakarta dan Bandung periode 1980-20oo Menuju Satu Daerah Aglomerasi ?, Jurnal Empirika, 17, 2(12).

Holmes, Thomas. J, 1998, The Effect of State Policies on The Location of Manufacturing Evidence from State Border, Journal of Political Economy, 106(4), 667-705.

Hoover, Edgar Malone, 1948, The Location of Economic, New York, McGraw-Hill.

Jaffe, Adam B, Manuel Trajtenberg and Michael S. Fogarty, 20oo, Knowledge Spillover and Patent Citations Evidence from Survey of Inventors, American Economic Review, 9o(2), 215-218.

Kerr, William R, 2008, Ethnic Scientific Communities and International Technology Diffusion, Review of Economics and Statistics, 9o(3), 518-537.

Kim, Sukkoo, 1999, Regions, Resources and Economics Geography Sources of United State Regional Comparative Advantage 1880-1987, Regional Science and Urban Economics, 29(1), 1-32.

Kuncoro, Mudrajad, 200o, Beyond Agglomeration and Urbanization, Gadjah Mada International Journal Business, 2(3).

Kuncoro, Mudrajad, 2002, Analisis Spasial dan Regional Studi Aglomerasi dan Kluster Industri Indonesia, Yogyakarta, UPP AMP-YKPN.

Laura Alfaro, Maggie Chen, 2014, The Global Agglomeration of Multinational Firms, National Bereau of Economic Research Working Paper, 15576.

Mankiw, N Gregory, 2007, Macroeconomics, Worth Publisher, New York, USA.

Ozekhome, H. O. (2020). International Trade Cost and Trade Flows Evidence from The West African Monetary Zone (WAMZ), Finance and Economics Review, 2(1).

Paulo Guimaraes, Octavio Figueiredo, Douglas Woodward, 200o, Agglomeration and The Location of Foreign DIrect Investment in Portugal, Journal of Urban Economics, 47(1), 115-135.

Puga, Diego, 2010, The Magnitude and Causes of Agglomeration Economies, Regional Science, 50(1), 203-219.

Menon, Carlo, 2008, The Bright Side of Gerrymanderring An Inquiry on The Determinants of Industrial Agglomeration in The United States, Unpublished.

Pimentel, M. S., Harper, B., \& Martin, E. J., 2016,. Addressing Poverty in Peru Degrowth Indigenous Local Farming and Technology Innovation, International Journal of Economic Developmen, vol 10(1), 104-147.

Redding, Stephen, 2010, The Empiries of New Economic Geography, Journal of Regional Science, 50(1), 297-311.

Redding, Stephen, 2011, Economic Geography A Review of The Theoritical and Empirical Literature, The Pulgrave Handbook of International Trade.

Rosenthal, Stuart and William C. Strange, 2001, The Determinants of Agglomeration, Journal of Urban Economics, 50(2), 191-229.

Rosenthal, Stuart and William C. Strange, 2003, Geography, Industrial Organization and Agglomeration, Review of Economics Statistics, 85(2), 377-393.

Rosenthal, Stuart and William C. Strange, 2004, Evidence on The Nature and Sources of Agglomeration Economies, in: Henderson, J. Vernon, Thisse, Jacques-Francois (eds), Handbook of Regional and Urban Economics, 4, 2119-2171.

Rotemberg, Julio J and Garth Saloner, 20oo, Competition and Human Capital Accumulation A Theory of Interregional Specialization and Trade, Regional Science and Urban Economics, 30(4), 373-404.

Silverman, Brian S, 1999, Technological Resources and The Direction of Corporate Diversification toward an Integration of The Resources-Based View and Transaction Cost-Economics, Management Science, 45(8), 1109-1124.

S.K Misra and U.K Puri, 2010, Economics of Development and Planning Theory and Practice, (12 ed), Himalaya Publishing House, 215-222.

Sodik, Jamzani dan Iskandar, Dedi, 2007, Aglomerasi dan Pertumbuhan Ekonomi Peran Karakteristik Regioinal di Indonesia, Jurnal Ekonomi \& Studi Pembangunan, 8(10), 117-129. 
Thomas A. Lubik, 2018, Indeterminacy and Learning: An Analysis of Monetary Policy in the Great Inflation, International Journal of Monetary Economics, 82, 85-106.

Yeaple, Stephen, 2003, The Complex Integration Strategies of Multinational Firms and Cross-Country Dependencies in The Structure of Foreign Direct Investment, Journal of International Economics, 16o(2), 293-314.

Yuliadi, Imamudin, 2020, Determinants of Economics Growth in Indonesia, Jurnal Ekonomi E Studi Pembangunan, $21(1), 125-136$

Zhang, W.B. (2016). Spatial agglomeration in a monetary multi-regional growth model with urban residential distribution. International Journal of Monetary Economics and Finance, 10(1), 68-95. 